\title{
Improved $\mathrm{VO}_{2 \mathrm{Max}}$ : The Effectiveness of Basic Soccer Training at a Young Age
}

\author{
Ridho Bahtra ${ }^{1,2^{*}}$, Moch. Asmawi ${ }^{3}$, Widiastuti $^{3}$, Firmansyah Dlis $^{3}$ \\ ${ }^{1}$ Doctoral Student of Postgraduate Faculty of Universitas Negeri Jakarta, 13220, Indonesia \\ ${ }^{2}$ Lecturer, Faculty of Sport Sciences, Padang State University, 25171, Indonesia \\ ${ }^{3}$ Lecturer in Postgraduate Faculty of Universitas Negeri Jakarta, 13220, Indonesia
}

Received April 15, 2020; Revised May 22, 2020; Accepted June 16, 2020

Copyright $(\mathcal{O} 2020$ by authors, all rights reserved. Authors agree that this article remains permanently open access under the terms of the Creative Commons Attribution License 4.0 International License

\begin{abstract}
The skill in managing the ball is a skill that must be possessed by every football player, but if the player has a low $\mathrm{VO}_{2 \mathrm{Max}}$, then the player will not be able to compete at the international level. Therefore, we need a training method to improve $\mathrm{VO}_{2 \mathrm{Max}}$ soccer players, in order to sustain the skills that they have. Therefore, the purpose of this study is to look at the differences between the two training methods aimed at improving $\mathrm{VO}_{2 \mathrm{Max}}$ soccer players. This research is a quantitative quasi-experimental research with post-test control group design. With a total of 76 participants, which are divided into two groups, namely the experimental group who are trained using basic techniques of efficient football and the control group using conventional training. All data obtained are searched for mean, min, max, and standard deviation and the difference between the two methods using independent sample t-test. There are differences between the two training methods in improving $\mathrm{VO}_{2 \mathrm{Max}}$ players. It was found that using effective soccer training methods had a difference of 12,963 to conventional training in improving $\mathrm{VO}_{2 \mathrm{Max}}$ players.
\end{abstract}

Keywords Effective Training Methods, Soccer, $\mathrm{VO}_{2 \mathrm{Max}}$

\section{Introduction}

Modern football style requires physical fitness or physical fitness and $\mathrm{VO}_{2 \mathrm{Max}}$ in particular. A talented soccer player may not be able to play a good and satisfying game if he is physically unfit and cannot maintain his physical fitness continuously $[1,2]$. The style of modern football is also increasingly demanding the ability to play the ball in high skills. These soccer characteristics involve the speed of pressure from the opposing player when a player is controlling the ball. The high pressure on the player who controls the ball makes the player does not have enough space to freely play the ball. In such conditions, players are required to have the ability to escape from the control of opponents, protect the ball so that it remains in control, and collectively arrange attacks through fast passes and directed in the condition of the ball remains in the mastery of the team (ball possession) [3,4]. The game of football is a sport that is prerequisite with skills. Even so, the functional movement patterns in the game of football which are known as "ball technique" skills can be divided into eight, namely: 1) kicking; 2) stop the ball (ball control); 3) carrying the ball (dribbling), 4) heading (heading); 5) feinting; 6) seize the ball (tackling); 7) throw-in; and 8) goal keeper [5]. Therefore, in football, high $\mathrm{VO}_{2 \max }$ and skills are needed to compete at the international level. Because, if you only have the skills or skills in managing a good ball, but do not have a high $\mathrm{VO}_{2 \max }$, then these players will not be able to compete at international and professional levels.

A good maximal consumption of oxygen or $\mathrm{VO}_{2 \mathrm{Max}}$ clearly illustrates that a person's level of physical fitness also has $\mathrm{VO}_{2 \mathrm{Max}}$ and good physical fitness in an athlete or soccer player can prevent or minimize the possibility of injury. Theoretically a consideration for coaches if most players have relatively less physical value compared to opponents then it is not possible to choose the type of total play (power) football but it is better to choose the classic type [6-9]. The duration of the soccer game $2 \times 45$ minutes is a soccer game where the movements when playing on the field are very complex and varied so that they require cruising capabilities throughout the game. For this reason, in addition to having excellent physical fitness, a soccer player should have a high aerobic capacity [10-12]. In connection with this indicator the KONI Center for Sports Sciences (PIO) sets a minimum standard of $60 \mathrm{cc}$ maximum aerobic ability for national team soccer players [13]. From this standard of physical ability, most soccer clubs are allegedly not capable enough to apply contemporary soccer 
styles. $\mathrm{VO}_{2 \text { Max's }}$ ability and player's skill level has a causal relation to the player's condition.

According to Kent (1994) the maximum aerobic capacity or $\mathrm{VO}_{2 \mathrm{Max}}$ is the maximum amount of oxygen that a person can breathe from air to then transport and use it in tissues [14]. According to Fox (1984), the maximum aerobic power is determined by factors: a) the function of the heart, lungs and blood vessels; b) the process of delivering oxygen to the tissue by erythrocytes involving heart function, blood volume and the number of red blood cells in terms of transfer of blood from inactive tissue to active muscle [15]. Then the maximum oxygen volume is one of the important factors to support athletes' achievements, especially in sports which are considered to have strength. The criteria for achieving maximal aerobic capacity as applied in the measurement of maximum aerobic capacity are: a) the occurrence of fatigue; b) the pulse rate is greater than 190 beats per minute; c) the respiratory exchange ratio is greater than 1 , and d) the level of lactic acid in the blood exceeds $100 \mathrm{mg}$ percent [16]. This criterion is used as a basis for assessing the measurement objectivity and requirements of a test. Maximum aerobic ability $\left(\mathrm{VO}_{2 \mathrm{Max}}\right)$ of a football player will support more intensive work and the ability to execute skills in high pressure situations from opposing players. Modern soccer style as described in theoretical studies requires physical fitness or physical fitness and $\mathrm{VO}_{2 \max }$ in particular [17]. During the 2 x 45 minutes of football matches the players ran an average of about eight to 13 kilo meters, running short distances and running mid-speed in turn (intermittent). A talented soccer player may not be able to play a good and satisfying game if he is physically unfit and cannot maintain his physical fitness continuously [18].

$\mathrm{VO}_{2 \mathrm{Max}}$ is the body's ability to consume oxygen maximally during activity and training [19-22]. The maximum volume of oxygen that can be consumed during continuous and gradually increasing intensive exercise, mainly uses the aerobic process. It is calculated in $\mathrm{ml} / \mathrm{kg} / \mathrm{min}$ using specific laboratory tests or field tests [23-25]. The maximum amount of oxygen that can be consumed during intense physical activity until fatigue finally occurs [26]. Many theories and literature explain the needs of $\mathrm{VO}_{2 \max }$ a football player. The average oxygen uptaken for international soccer teams ranges from 55 to 68 $\mathrm{ml} / \mathrm{kg} / \mathrm{min}$ [27], 48-62 ml/kg/min [28]. Professional 56.5 $\mathrm{ml} / \mathrm{kg} / \mathrm{min}$; Amateur $55.7 / \mathrm{kg} / \mathrm{min}$ [29], $\mathrm{VO}_{2 \max }$ football players aged 22-28 years are for men $54 \mathrm{ml} / \mathrm{kg} / \mathrm{min}-64$ $\mathrm{ml} / \mathrm{kg} / \mathrm{min}$ and girls $50 \mathrm{ml} / \mathrm{kg} / \mathrm{min}-60 \mathrm{ml} / \mathrm{kg} / \mathrm{min}$ [21]. While Taylor (2016) states in football, the best players can reach $\mathrm{VO}_{2 \max }$ levels of $65-70 \mathrm{ml} / \mathrm{kg} / \mathrm{min}$, depending on their age, level of individual performance and position on the pitch. A $\mathrm{VO}_{2 \max }$ of $60-62 \mathrm{ml} / \mathrm{kg} / \mathrm{min}$ is already considered to be a decent reserve for a footballer and more so for players aged 16-17 years [25].

The need for $\mathrm{VO}_{2 \max }$ and endurance is quite a lot in football games, requiring coaches to design training models that can improve $\mathrm{VO}_{2 \max }$. In soccer the training model that is designed should be more specific and use a ball. Ideally exercises to increase endurance and $\mathrm{VO}_{2 \max }$ should be done using a ball [30-33]. Improving the physical condition of soccer, players should use specific exercises, such as small side games, soccer technique training, and ball-specific position training [34, 35]. High-intensity training in the form of special soccer games such as small side games and soccer training drills can increase aerobic capacity $\left(\mathrm{VO}_{2 \max }\right)$ [36]. The application of training methods for endurance, strength, speed must always be specific to football [37].

Based on the theories that have been put forward then a new form of $\mathrm{VO}_{2 \max }$ training is made which is based on basic soccer training techniques. Usually, $\mathrm{VO}_{2 \max }$ increases soccer players with high-intensity exercises in the form of special soccer games such as small side games [36]. However, researchers develop a method to improve the $\mathrm{VO}_{2 \max }$ of under 18 soccer players, namely by practicing effective basic soccer techniques. Usually the basic football training technique, is an exercise that is usually done to improve soccer's basic technical skills. But in this study, it is modified into exercises to improve $\mathrm{VO}_{2 \max }$. Implementation in this exercise is exactly like ordinary technical training, so that players do not feel bored which has been a problem for coaches in doing $\mathrm{VO}_{2 \max }$ training. This dive practice only runs with the specified duration of time changing to the basic form of technical training in soccer. The basic elements of football techniques such as passing, ball control, dribbling and shooting are used as media for training to increase $\mathrm{VO}_{2 \max }$ by modifying several items, which include intensity in doing, volume in doing, number of sets and recovery in training. Modifications are made based on the principles of training and the imposition of training on the physical condition of football. On the basis of all that, the purpose of this study is to look at the effectiveness of basic soccer training techniques in improving $\mathrm{VO}_{2 \max }$ young soccer players.

Therefore, the aim of this study is to look at the effectiveness of the basic techniques of effective soccer training as well as the difference in using other techniques to improve $\mathrm{VO}_{2 \mathrm{Max}}$ soccer players. With the following research questions

1. What is the effectiveness in conducting basic soccer technical training methods effectively in $\mathrm{VO}_{2 \mathrm{Max}}$ soccer players?

2. Is there a difference between using effective basic soccer training methods in $\mathrm{VO}_{2 \mathrm{Max}}$ and conventional techniques for improving $\mathrm{VO}_{2 \mathrm{Max}}$ soccer players?

\section{Materials and Methods}

This research is a quasi-experimental study with a post-test control group design. That is done to investigate causal hypotheses about causes that can be manipulated by comparing one or more experimental groups that are 
treated with one comparison group that is not treated [38]. The design of this study is applied because it is in accordance with the objectives of the study, where the aim is to find out whether there is a difference between the practice of basic effective soccer techniques and other techniques to improve $\mathrm{VO}_{2 \mathrm{Max}}$ soccer players. This research uses descriptive statistics in the form of mean, min, max, and standard deviation and uses inferential statistics. The inferential statistics used are independent sample t-tests.

Table 1. Posttest Non-Equivalent Control Group Design

\begin{tabular}{|c|c|c|}
\hline Group & Treatment & Posttest \\
\hline Experimental & $\begin{array}{c}\text { Basic soccer effective training } \\
\text { techniques }\end{array}$ & $\mathrm{O}_{1}$ \\
\hline Control & $\begin{array}{c}\text { Conventional Training (small side } \\
\text { games) }\end{array}$ & $\mathrm{O}_{2}$ \\
\hline
\end{tabular}

The subjects in this study are soccer players aged U-18 years, total 76 people. In the experimental group there are 38 players and in the control group there are also 38 players. In the experimental group using the basic techniques of effective soccer training and in group control using conventional training. The sample collection technique uses a purposive sampling method. Purposive sampling is a sampling technique based on researchers' criteria [39]. The criteria in this study are players under the age of 18 years. Data collection procedures for referring [40], are explained in the figure 1.

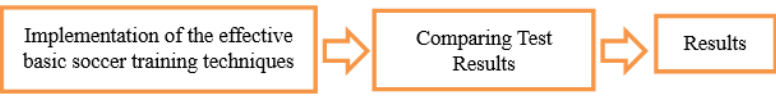

Figure 1. Data Collection

Based on Figure 1, it is seen that the first activity carried out is applying effective basic soccer training techniques to improve $\mathrm{VO}_{2 \mathrm{Max}}$ players which are only done in the experimental group, then for the control group applying conventional exercises. After training is completed, the Yo - Yo IR test [40] is given to see if there are differences in $\mathrm{VO} 2_{\text {Max }}$ players who use effective basic soccer training techniques or those who only use conventional training.
After the data is collected then the data is compiled, then the data is processed using the independent sample t-test analysis technique.

\section{Results and Discussion}

Research findings are explained in this section. The Mean, Min, Max, and Standard deviation, post-test results to show the impact of effective basic football training techniques on under 18 soccer players are presented in table 2 below.

From table 2, we can see that the experimental class has the highest $\mathrm{VO}_{2 \mathrm{Max}}$ value of 58.54 and the lowest of 44.8, while for the control group has a $\mathrm{VO}_{2 \mathrm{Max}}$ value of 51.53 for the highest, and for the lowest of 43.8. From this we can see that the use of training with the basic techniques of football is effective, more effective than the use of conventional training techniques. Although the standard for professional players under 18 is $54-64 \mathrm{ml} / \mathrm{kg} / \mathrm{min}$ [21]. However, this has not been able to strengthen the difference between the use of the training method, so inferential testing is done using an independent sample t-test, which can be seen in table 3 .

From table 3 it can be seen that the value is obtained (t-arithmetic) with the value of $t$ table. T-table values can be found in the t table with a significance value of 0.05 (2-sided test) with a degree of freedom (df) 76. In this study, the results for $t$ table are 1.66515. Whereas the value of $t$ arithmetic can be seen in table 3 . (column $t$ ) which is 12.963. Hypothesis testing criteria if the value of $t$ table is greater than $t$ arithmetic, then there is no difference (Cramer, 2003). So, it can be concluded that there is a significant difference for $\mathrm{VO}_{2 \text { Max }}$ players under 18 between the control group using conventional training techniques and the experimental group using effective soccer training techniques. It can be seen from table 3 that the average value of $\mathrm{VO}_{2 \mathrm{Max}}$ players is 2.51 , which means that basic soccer training can effectively increase $\mathrm{VO}_{2 \mathrm{Max}}$ soccer players under 18.

Table 2. Gap scores of $\mathrm{VO}_{2 \mathrm{Max}}$ under 18 soccer players who use basic soccer training techniques effectively with conventional training

\begin{tabular}{|c|c|c|c|c|}
\hline Group & Max & Min & Mean & SD \\
\hline Experiment & 58.54 & 44.8 & 49.64 & 2.51 \\
\hline Control & 51.53 & 43.8 & 48.28 & 1.83 \\
\hline
\end{tabular}

Table 3. Results of the Independent sample t-test for effective basic soccer training

\begin{tabular}{|c|c|c|c|c|c|c|}
\hline & & \multirow{2}{*}{$\mathrm{T}$} & \multirow{2}{*}{ Df } & \multirow{2}{*}{ Mean } & \multirow{2}{*}{ Std. Deviation } & \multicolumn{2}{|c|}{$\begin{array}{c}\text { 95\% confidence } \\
\text { interval }\end{array}$} \\
\cline { 3 - 7 } & & & & & Lower & Upper \\
\hline \multirow{2}{*}{$\begin{array}{c}\text { Basic soccer effective } \\
\text { training techniques }\end{array}$} & 12.963 & 76 & 49.64 & 2.51 & 12.236 & .4120 \\
\cline { 2 - 7 } & 12.963 & 96.321 & 48.24 & 1.83 & 11.935 & .5615 \\
\hline
\end{tabular}


Based on the results obtained (see table 2), Basic soccer effective training techniques are more effective than Conventional Training (small side games). That is because, on the basis of effective soccer training, researchers have modified their training, so as to improve the $\mathrm{VO}_{2 \max }$ of soccer players, such as in passing, ball control, dribbling and shooting, what is modified is an intensity in doing, volume in doing, number of sets and recovery in training, but the modifications made remain based on the principle of training the physical condition of football. From table 2, we can see that, the use of conventional methods can increase the $\mathrm{VO}_{2 \max }$ of the player by $51.53 \mathrm{ml} / \mathrm{kg} / \mathrm{min}$. Much different from the effective basic training technique, which is able to increase by $58.54 \mathrm{ml} / \mathrm{kg} / \mathrm{min} V_{2 \max }$ soccer players under 18 , and it has entered the $\mathrm{VO}_{2 \mathrm{Max}}$ standard for young players. Because $\mathrm{VO}_{2 \max }$ standard young players are at $54-64 \mathrm{ml} / \mathrm{kg} / \mathrm{min}$ [21].

$\mathrm{VO}_{2 \mathrm{Max}}$ is the body's ability to consume oxygen maximally during activity and training [19-22]. The maximum volume of oxygen that can be consumed during continuous and gradually increasing intensive exercise, mainly using the aerobic process. It is calculated in $\mathrm{ml} / \mathrm{kg} / \mathrm{min}$ using specific laboratory tests or field tests [23-25]. The maximum amount of oxygen that can be consumed during intense physical activity until finally fatigue occurs [26]. Many theories and literature explain the $\mathrm{VO}_{2 \max }$ needs of a soccer player. The average oxygen uptaken for international soccer teams ranges from 55 to 68 $\mathrm{ml} / \mathrm{kg} / \mathrm{min}$ [27], 48-62 $\mathrm{ml} / \mathrm{kg} / \mathrm{min}$ [28]. professional 56.5 $\mathrm{ml} / \mathrm{kg} / \mathrm{min}$; Amateur $55.7 \mathrm{ml} / \mathrm{kg} / \mathrm{min}$ [29], $\mathrm{VO} 2 \mathrm{max}$ football players aged 22-28 years are for men $54 \mathrm{ml} / \mathrm{kg} / \mathrm{min}$ - $64 \mathrm{ml} / \mathrm{kg} / \mathrm{min}$ and girls $50 \mathrm{ml} / \mathrm{kg} / \mathrm{min}-60 \mathrm{ml} / \mathrm{kg} / \mathrm{min}$ [21]. While Taylor (2016) states In football, the best players can reach $\mathrm{VO}_{2 \max }$ levels of $65-70 \mathrm{ml} / \mathrm{kg} / \mathrm{min}$, depending on their age, level of individual performance and position on the pitch. A $V_{2 \max }$ of $60-62 \mathrm{ml} / \mathrm{kg} / \mathrm{min}$ is already considered to be a decent reserve for a footballer and more so for players aged 16-17 years [25].

The need for $\mathrm{VO}_{2 \max }$ and endurance is quite a lot in football games, requiring coaches to design training models that can improve $\mathrm{VO}_{2 \max }$. In soccer the training model that is designed should be more specific and use a ball. Ideally exercises to increase endurance and $\mathrm{VO}_{2 \max }$ should be done using a ball [30-33]. Improving the physical condition of soccer players should use specific exercises, such as small side games, soccer technique training, and ball-specific position training [34, 35]. High-intensity training in the form of special soccer games such as small side games and soccer training drills can increase aerobic capacity $\left(\mathrm{VO}_{2 \max }\right)$ [36]. The application of training methods for endurance, strength, speed must always be specific to football [37].

Increasing $\mathrm{VO}_{2 \max }$ will improve player performance in matches such as distance traveled, intensity, number of sprints, and the amount of player involvement with the ball $[30,41]$. Players with higher $\mathrm{VO}_{2 \max }$ increase the distance traveled and increase their potential in influencing the final results of a football match [42]. Players who have large $\mathrm{VO}_{2 \max }$ have the supply and creation of energy to move without limits, have a recovery period that is very fast so that athletes can work long hours without experiencing significant fatigue [22].

Basic soccer training techniques or $\mathrm{VO}_{2 \max }$ exercises that use the ball as a medium have several advantages, including: 1) in addition to increasing $\mathrm{VO}_{2 \max }$, it also improves the player's basic technical skills, because players will always be in contact with the ball, 2) eliminating player boredom in $\mathrm{VO}_{2 \max }$ training. Training using the ball will provide many variations of training, such as passsing, ball control, dribbling, shooting, combination play and others so that players do not get bored in undergoing training. 3) facilitates the trainer in organizing and controlling the exercises. $\mathrm{VO}_{2 \max }$ exercises such as cross country, fartlek, intervals and circuits require the trainer to organize and always control the players to keep running, 4) increase the motivation of players in undergoing $\mathrm{VO}_{2 \max }$ training, because this exercise has an attraction in various forms of training.

Besides that Schlumberger (Fitness expert) explains "He sees the goals of soccer-specific endurance training as follows: 1) 90 to 120 minutes optimal performance readiness for all typical motion sequences in soccer, 2) Optimal capacity for high-intensity explosive performance in individual actions, 3) Optimal capacity for repeated high-intensity explosive performance for the duration of the game, 4) Maintaining the same intensity for a longer period of time, 5) Achieving a higher intensity within the same period of time, 6) Good cardiovascular capacity , 7) Good muscle metabolic function [43].

$\mathrm{VO}_{2 \max }$ training using the ball will provide an update on the soccer player's $\mathrm{VO}_{2 \max }$ training. There are many benefits and advantages of specific football training or physical training with ball [44-46]. So it is very important for the coach to provide physical training, especially $\mathrm{VO}_{2 \max }$ by using the ball as a medium. However, not only this exercise, maybe the trainer can modify or manipulate new forms of training so that more forms of training are available. This will certainly add a reference to the form of VO2max training for soccer coaches.

\section{Conclusions}

Increasing $\mathrm{VO}_{2 \mathrm{Max}}$ young players under 18 is very important to do, and by having high $\mathrm{VO}_{2 \mathrm{Max}}$ it will support these players in a match. Because, if you only have good skills, but not supported by high $\mathrm{VO}_{2 \mathrm{Max}}$, then these players cannot compete with other international players. Therefore, through training that applies the basic techniques of effective soccer training it can improve the $\mathrm{VO}_{2 \max }$ of young soccer players compared to conventional training. This can be seen from the calculated $t$ value greater than $t$ 
table, and then there is a significant difference between the use of the two training models in improving $\mathrm{VO}_{2 \mathrm{Max}}$ players. This exercise is very suitable for young players (youth), because in addition to improving $\mathrm{VO}_{2 \max }$ is also able to improve the basic technical skills of football players. In addition, this exercise can increase motivation and eliminate players' boredom during the training process

\section{Acknowledgements}

Thanks to all respondents who have been willing to be a sample in this study, so that this study can be completed as desired.

\section{REFERENCES}

[1] H. Hornby. Uppies \& Downies. The Extraordinary Football Games of Britain. Swindon: English Heritage, 2008.

[2] D. Jinxia., \& J. A. Mangan. Ascending then Descending? Women's Soccer in Modern China. Soccer \& Society, 3(2), 1-18. 2002. doi:10.1080/714004877

[3] M. T, Elferink-Gemser., B. C. H, Huijgen., M. Coelho-E-Silva., K. A. P. M, Lemmink., \& C. Visscher. The changing characteristics of talented soccer players - a decade of work in Groningen. Journal of Sports Sciences, 30(15), 1581-1591. 2012. doi:10.1080/02640414.2012.725 854

[4] G. Curry. 'Stunted Growth: The Early Development of Football in Derby and South Derbyshire.' Soccer and Society. 19(1), 24-34. 2018. doi:10.1080/14660970.2016.1 276241.

[5] G. Curry. The making of modern soccer: a product of multiple interdependencies. Soccer \& Society, 1-11.2019. doi:10.1080/14660970.2019.1680500

[6] M. A, Hammami., A. Ben Abderrahmane., A. Nebigh., E. Le Moal., O. Ben Ounis., Z. Tabka., \& H. Zouhal. Effects of a soccer season on anthropometric characteristics and physical fitness in elite young soccer players. Journal of Sports Sciences, 31(6), 589-596. 2013. doi:10.1080/02640414.2012.746721

[7] G. Baquet., S. Berthon., G. Dupont., N. Blondel., C. Fabre., \& E. Van Praagh. Effects of high intensity intermittent training on peak VO2 in prepubertal children. International Journal of Sports Medicine, 23, 439-444. 2002.

[8] A. Baxter-Jones., H. Goldstein., \& P. Helms. The development of aerobic power in young athletes. Journal of Applied Physiology, 75, 1160-1167. 1993.

[9] C. Castagna., V. Manzi., F. Impellizzeri., M. Weston., \& J. C, Barbero Alvarez. Relationship between endurance field tests and match performance in young soccer players. Journal of Strength and Conditioning Research, 24, 3227-3233, 2010.

[10] J. Francisco., L. Marti'n., \& A. C, Gallego. Deficits of accounting in the valuation of rights to exploit the performance of professional players in football clubs. A case study. Journal of Management Control, 22, 335-357. 2011.

[11] F. Le Gall., C. Carling., M. Williams., \& T. Reilly. Anthropometric and fitness characteristics of international, professional and amateur male graduate soccer players from an elite youth academy. Journal of Science and Medicine in Sport, 13, 90-95. 2010.

[12] G. Markovic., \& P. Mikulic, P. (2011). Discriminative ability of the yo-yo intermittent recovery test (level 1) in prospective young soccer players. Journal of Strength and Conditioning Research, 25, 2931-2934.

[13] Thomas Cup dan Uber Cup Indonesia. Kumpulan Makalah Diskusi Ilmiah Berkala XXVI-XXXV PIO KONI Pusat.

[14] M. Kent. The Oxford Dictionary of Sport Science and Medicine. Oxford University Press. 1994.

[15] F. L, Edward. Sport Physiology, second Edition. United State: CBS College Publishing. 1984.

[16] F. L, Edward., W. B, Richard., L. F, Merle L. The Physiological Basis for Exercise and Sport, fifth ed. Iowa: WCB Brown \& Benchmark. 1993.

[17] P. Nikoladis., \& N. Karidis. Physique and body composition in soccer players across adolescence. Asian Journal of Sports Medicine, 2, 75-82. 2011.

[18] U. Azcárate., A. Los Arcos., P. Jiménez-Reyes., \& J. Yanci. Are acceleration and cardiovascular capacities related to perceived load in professional soccer players? Research in Sports Medicine, 1-15. 2019. doi:10.1080/15438627.2019. 1644642

[19] J. Hoff., U. Wisloff., L. C, Engen., O. J, Kemi., \& J. Helgerud. Soccer specific aerobic endurance training. 218 222. 2002.

[20] T. O, Bompa., \& G. G, Haff. Periodization Theory and Methodology of Training (Fifth Edit; M. S. Bahrke, ed.). United States: Human Kinetics. 2009.

[21] D. Z, Sidik., P. L, Pesurnay., \& L. Afari. Pelatihan Kondisi Fisik (Nita, ed.). Bandung: PT Remaja Rosdakarya. 2019.

[22] J. Turnley. $\mathrm{VO}_{2 \max }$ : HOW CAN AN ENDURANCE ATHLETE USE IT TO OBTAIN PEAK PERFORMANCE? i(16), 9 .

[23] FIFA. (n.d.). FIFA COACHING MANUAL. Retrieved from www.fi fa.com

[24] Taylor, J. J. Youth Football. www.FIFA.com, 257. 2016.

[25] Watulingas, I., Rampengan, J. J. V., \& Polii, H. PENGARUH LATIHAN FISIK AEROBIK TERHADAP VO2 MAX PADA MAHASISWA PRIA DENGAN BERAT BADAN LEBIH (OVERWEIGHT). 1, 1064-1068. 2013.

[26] J. Hoff. Training and testing physical capacities for elite soccer players. 414. 2007. https://doi.org/10.1080/0264041 0400021252

[27] M. Slimani., H. Znazen., B. Miarka., \& N. L, Bragazzi. Maximum Oxygen Uptake of Male Soccer Players According to their Competitive Level, Playing Position and 
Age Group : Implication from a Network Meta-Analysis by. 66, 233-245. 2019. https://doi.org/10.2478/hukin-2018-006 0

[28] C. M, Wells., A. M, Edwards., E. M, Winter., M. L, Fysh., \& B. Drust. Sport-specific fitness testing differentiates professional from amateur soccer players where $\mathrm{VO}_{2 \max }$ and VO2 kinetics do not. 52(3), 245-254. 2012.

[29] J. A. N, Helgerud., L. C, Engen., U. Wisløff., \& J. A. N, Hoff. Aerobic endurance training improves soccer performance. (13), 1925-1931. 2001.

[30] M. Russell., W. Sparkes., J. Northeast., C. J, Cook., T. D, Love., R. M, Bracken., \& L. Kilduff. Changes in acceleration and deceleration capacity throughout professional soccer match-play. Journal of Strength and Conditioning Research, 30(10), 2839-2844. 2016.

[31] B. J, McMorrow., M. Ditroilo., \& B. Egan. Effect of heavy resisted sled sprint training during the competitive season on sprint and change-of-direction performance in professional soccer players. International Journal of Sports Physilogy and Performance, 31, 1-25. 2019.

[32] A. Martín-García., A. Gómez Díaz., P. S, Bradley., F. Morera., \& D. Casamichana. Quantification of a professional football team's external load using a microcycle structure. Journal of Strength and Conditioning Research, 32(12), 3511-3518. 2018.

[33] A. Jaspers., M. S, Brink., S. G, Probst., W. G, Frencken., \& W. F, Helsen. Relationships between training load indicators and training outcomes in professional soccer. Sports Medicine, 47(3), 533-544. 2017.

[34] W. Abbott., G. Brickley., N. J, Smeeton., \& S. Mills. Individualizing acceleration in English Premier League academy soccer players. Journal of Strength and Conditioning Research, 32(12), 3503-3510. 2018.

[35] L. Radziminski., P. Rompa., W. Barnat., R. Dargiewicz., \& Z. Jastrzebski. A Comparison of the Physiological and
Technical Effects of High-Intensity Running and Small-Sided Games in Young Soccer Players. International Journal of Sports Science \& Coaching Volume, 8(3), 455466. 2013.

[36] F. Seeger. The Soccer Games and Drills Compendium "350 Smart and Practical Games to Form Intelligent Players-For All Levels. 2016.

[37] L. Cohen., L. Manion., \& K. Morrison. Research Methods in Education: Routledge. 2007

[38] F. N, Kerlinger. Foundations of behavioral research. Yogyakarta: Gadjah Mada, 2014.

[39] J. W, Creswell. Research Design Qualitative, Quantitative, And Mixed Method Aproach. Singapore: SAGE Publications Asia-Pacific, 2012.

[40] Bangsbo, J., \& Mohr, M. (2015). Fitness Testing in Football: Fitness Training in Soccer II. Bangsbosport.

[41] R. P, Alexander., \& C. M, Mier. Intermittent vs Continuous Graded Exercise Test for VO 2 max in College Soccer Athletes. (15). 2011.

[42] J. H, Ishee., \& B. Foster. Aerobic Endurance Training Improves Soccer Performance. (November 2014), 13-15. 2013. https://doi.org/10.1080/07303084.2003.10608354

[43] J. Ingebrigtsen., M. Bendiksen., M. B, Randers., C. Castagna., P. Krustrup., \& A. Holtermann. Yo-Yo IR2 testing of elite and sub-elite soccer players: Performance, heart rate response and correlations to other interval tests. Journal of Sports Sciences, 30(13), 1337-1345. 2012.doi:10.1080/02640414.2012.711484

[44] T. Stølen., K. Chamari., C. Castagna., \& U. Wisløff. Physiology of soccer: An update. Sports Medicine, 35, 501536. 2005.

[45] M. Svensson., \& B. Drust. Testing soccer players. Journal of Sports Sciences, 23, 601-618. 2005. 